University of Wollongong

Research Online

Faculty of Engineering - Papers (Archive)

Faculty of Engineering and Information

Sciences

$1-1-2007$

\title{
Guidelines for landslide susceptibility, hazard and risk zoning for land use planning
}

Phillip N. Flentje

University of Wollongong, pflentje@uow.edu.au

Anthony Miner

University of Wollongong, aminer@uow.edu.au

Graham Whitt

Shire of Yarra Ranges, g.whitt@yarraranges.vic.gov.au

Robin Fell

University of New South Wales, r.fell@unsw.edu.au

Follow this and additional works at: https://ro.uow.edu.au/engpapers

Part of the Engineering Commons

https://ro.uow.edu.au/engpapers/2823

\section{Recommended Citation}

Flentje, Phillip N.; Miner, Anthony; Whitt, Graham; and Fell, Robin: Guidelines for landslide susceptibility, hazard and risk zoning for land use planning 2007, 13-36.

https://ro.uow.edu.au/engpapers/2823

Research Online is the open access institutional repository for the University of Wollongong. For further information contact the UOW Library: research-pubs@uow.edu.au 


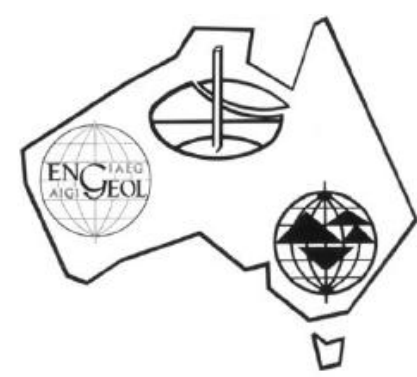

Australian

Geomechanics

Society

\section{Extract from}

\section{Australian Geomechanics}

Journal and News of the Australian Geomechanics Society Volume 42 No 1 March 2007

\section{Extract containing:}

"Guideline for Landslide Susceptibility, Hazard and Risk Zoning for Land Use Planning"

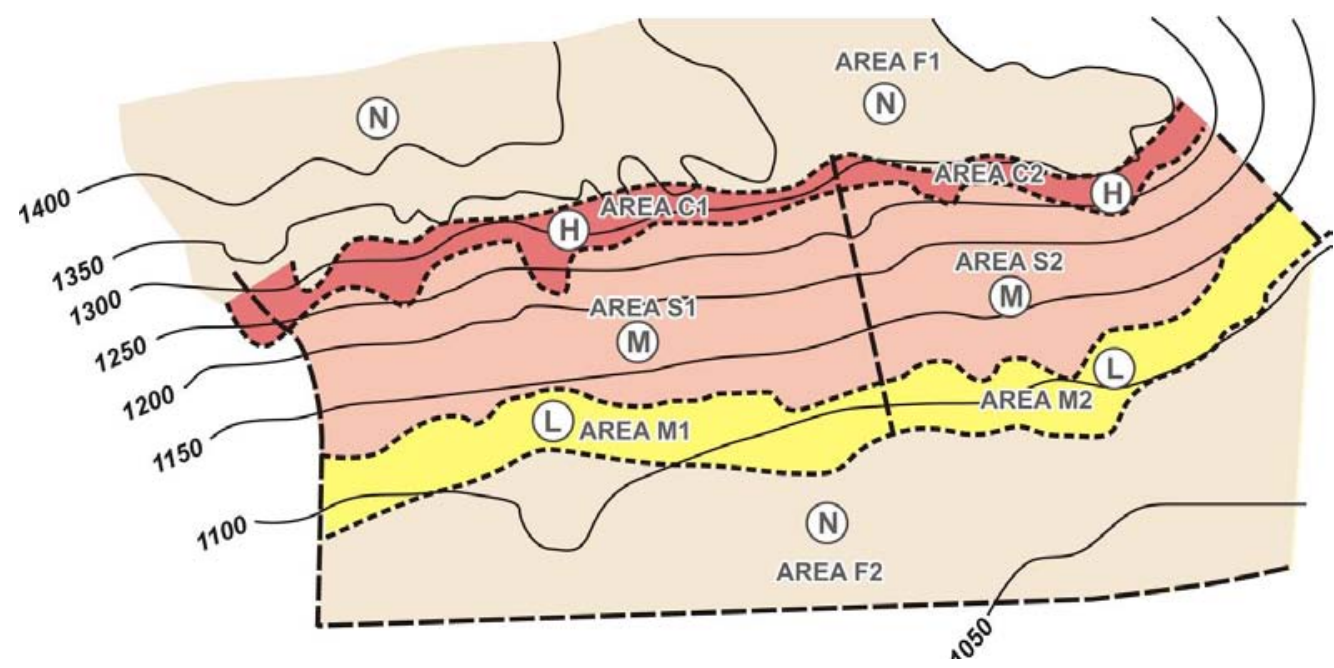

Landslide Risk Management 


\title{
GUIDELINE FOR LANDSLIDE SUSCEPTIBILITY, HAZARD AND RISK ZONING FOR LAND USE PLANNING
}

\author{
Australian Geomechanics Society Landslide Zoning Working Group \\ TABLE OF CONTENTS
}

INTRODUCTION

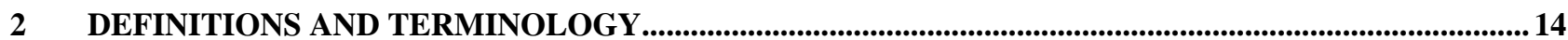

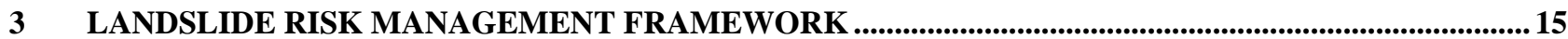

4 DESCRIPTION OF LANDSLIDE SUSCEPTIBILITY, HAZARD AND RISK ZONING FOR LAND USE

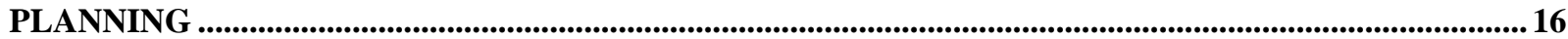

5 GUIDANCE ON WHERE LANDSLIDE ZONING IS USEFUL FOR LAND USE PLANNING...................17

6 SELECTION OF THE TYPE AND LEVEL OF LANDSLIDE ZONING .....................................................19

7 LANDSLIDE ZONING MAP SCALES AND DESCRIPTORS FOR SUSCEPTIBILITY, HAZARD AND

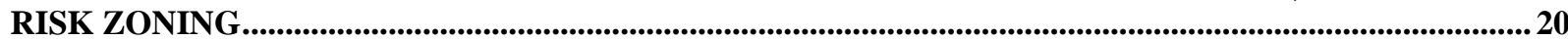

8 METHODS FOR LANDSLIDE ZONING FOR LAND USE PLANNING .................................................... 23

9 RELIABILITY OF LANDSLIDE ZONING FOR LAND USE PLANNING ....................................................29

10 APPLICATION OF LANDSLIDE ZONING FOR LAND USE PLANNING.................................................. 30

11 HOW TO BRIEF AND SELECT A GEOTECHNICAL PROFESSIONAL TO UNDERTAKE A ZONING

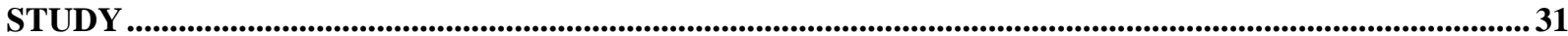

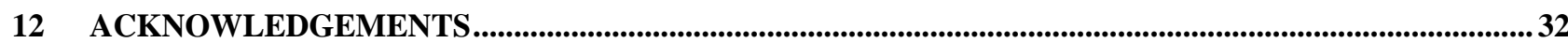

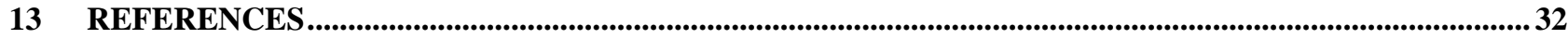

APPENDIX A - DEFINITION OF TERMS ..................................................................................................... 34

APPENDIX B - TASKFORCE MEMBERS........................................................................................................... 36

APPENDIX C - JTC-1 MEMBERS ……………….................................................................................................... 36

\section{$1 \quad$ INTRODUCTION}

There are a number of natural hazards which are relevant to urban, residential, rural and undeveloped property throughout Australia. These include flooding, bush fire, coastal processes and landslides. This guideline addresses landslide susceptibility, hazard and risk zoning for land use planning.

In 1998, following the Thredbo landslide in which 18 persons were killed, the Institution of Engineers Australia and the Australian Geomechanics Society (AGS) formed a Taskforce on the Review of Landslides and Hillside Construction Standards. The Taskforce after reviewing the Australian Standards and relevant codes on landslides and hillside construction concluded that they were inadequate and recommended the production of four guidelines:

- $\quad$ Landslide hazard zoning for urban areas, roads and railways

- $\quad$ Slope management

- $\quad$ Site investigations, design, construction and maintenance

- $\quad$ Landslide risk assessment

The Australian Geomechanics Society “Landslide Risk Management Concepts and Guidelines”, already under preparation at the time of the Thredbo landslide, was published in 2000 (AGS 2000, 2002). This document touched on all four areas but mainly addressed the fourth. It is used extensively throughout Australia.

In 2005 the Australian Geomechanics Society in collaboration with the Sydney Coastal Councils Group, was successful in obtaining funding under the Australian governments' National Disaster Mitigation Program (NDMP) to further the development of the guidelines which had been recommended by the Taskforce. Work to prepare these guidelines has 


\section{GUIDELINE FOR LANDSLIDE SUSCEPTIBILITY, HAZARD AND RISK ZONING}

progressed in 2005 and 2006 and has involved extensive consultation with those involved in landslide mapping for land use planning and the application of such mapping for planning in local government.

This Guideline for Landslide Susceptibility, Hazard and Risk Zoning for Land Use Planning provides:

- Definitions and terminology.

- Description of the types and levels of landslide zoning.

- Guidance on where landslide zoning and land use planning is necessary to account for landslides.

- Definitions of levels of zoning and suggested scales for zoning maps taking into account the needs and objectives of land-use planners and regulators and the purpose of the zoning.

- Guidance on the information required for different levels of zoning taking account the types of landslides.

- Guidance on the reliability, validity and limitations of the investigation methods.

- Advice on the required qualifications of the persons carrying out landslide zoning and advice on the preparation of a brief for consultants to conduct landslide zoning for land use planning.

The guideline considers landslides occurring in natural slopes and from failure of constructed slopes including cuts, fills and retaining walls and the impact of the landslides on the area to be zoned. It is intended for use by local, state and national government officials, geotechnical professionals, land use planners and project managers.

This guideline has been developed at the same time as similar guidelines prepared by the JTC-1 The Joint International Committee on Landslides and Engineered Slopes and there has been an interchange of concepts and detailed inputs between the two guidelines.

Through the NDMP, Australian governments (at Commonwealth, State and Local Government levels) are also funding the development of a Practice Note Guideline (AGS 2007c) to supersede the Landslide Risk Management Guideline (AGS 2000, AGS 2002), and a series of GeoGuides on Slope Management and Maintenance (AGS 2007e).

\section{DEFINITIONS AND TERMINOLOGY}

\subsection{DEFINITIONS}

Definitions for terms used in landslide zoning and risk management are given in Appendix A. These definitions are based on IUGS (1997), with some amendments in matters of detail based on internationally adopted definitions prepared by The International Society of Soil Mechanics and Geotechnical Engineering (ISSMGE) Technical Committee 32. These definitions should be used for all zoning, reports and land use planning documents. It is recommended that the definitions are attached to these documents so there is no misunderstanding of the terms.

Definitions of the main terms are:

- Landslide. The movement of a mass of rock, debris, or earth (soil) down a slope.

- Landslide Inventory. An inventory of the location, classification, volume, activity and date of occurrence of individual landslides in an area.

- Landslide Susceptibility. A quantitative or qualitative assessment of the classification, volume (or area) and spatial distribution of landslides which exist or potentially may occur in an area. Susceptibility may also include a description of the velocity and intensity of the existing or potential landsliding.

- Hazard. A condition with the potential for causing an undesirable consequence. The description of landslide hazard should include the location, volume (or area), classification and velocity of the potential landslides and any resultant detached material and the probability of their occurrence within a given period of time. Landslide hazard includes landslides which have their source in the area or may have their source outside the area but may travel on to or regress into the area.

- Risk. A measure of the probability and severity of an adverse effect to health, property or the environment. Risk is often estimated by the product of probability and consequences. However, a more general interpretation of risk involves a comparison of the probability and consequences in a non-product form. For these guidelines risk is further defined as:

(a) For life loss, the annual probability that the person most at risk will lose his or her life taking account of the landslide hazard and the temporal spatial probability and vulnerability of the person.

(b) For property loss, the annual probability of the consequence or the annualised loss taking account of the elements at risk, their temporal spatial probability and vulnerability.

- Elements at Risk. The population, buildings and engineering works, economic activities, public services utilities, infrastructure and environmental features in the area potentially affected by the landslide hazard. 


\section{GUIDELINE FOR LANDSLIDE SUSCEPTIBILITY, HAZARD AND RISK ZONING}

- Vulnerability. The degree of loss to a given element or set of elements within the area affected by the landslide hazard. It is expressed on a scale of 0 (no loss) to 1 (total loss). For property, the loss will be the value of the damage relative to the value of the property; for persons, it will be the probability that a particular life (the element at risk) will be lost, given the person(s) is (are) affected by the landslide.

- Zoning. The division of land into homogeneous areas or domains and their ranking according to degrees of actual or potential landslide susceptibility, hazard or risk.

In this guideline use of the word 'landslide' implies both existing (or known landslides) and potential landslides which a practitioner might reasonably predict based on the relevant geology, geometry and slope forming processes. Such potential landslides may be of varying likelihood of occurrence.

The term landslip is sometimes used to describe landslides but is not the recommended term.

It is noted that the term "zoning" has particular application by planners in Australia. This document uses the term as it best describes the process and is used internationally. To avoid confusion, those preparing landslide zoning using this document should always refer to " landslide susceptibility zoning", "landslide hazard zoning" and "landslide risk zoning".

\section{$2.2 \quad$ LANDSLIDE CLASSIFICATION AND TERMINOLOGY}

It is important that those carrying out landslide mapping use consistent terminology to classify and describe the landslides. It is recommended that the classifications of Cruden and Varnes (1996), Varnes (1978) or Hutchinson (1988) and terminology described in IAEG (1990) be used. These are reproduced in AGS (2007c).

\section{LANDSLIDE RISK MANAGEMENT FRAMEWORK}

Since the publication of AGS (2000), many local government authorities have required a quantitative risk assessment approach for assessment of life loss risk for individual building developments. They have generally accepted qualitative or semi-quantitative assessment of property risk. These assessments are carried out using the risk based framework described in AGS (2000) and AGS (2002).

Figure 1 summarizes the framework for landslide risk management. This is taken from Fell et al. (2005) and represents a framework widely used internationally. It was the basis for the State of the Art papers and invited papers at the International Conference on Landslide Risk Management held on Vancouver in May 2005 and is consistent with AGS (2000), AGS (2002)and AGS (2007c).

It is recommended that this general framework be used for landslide susceptibility, hazard and risk zoning whether a quantitative or qualitative approach is being taken. 


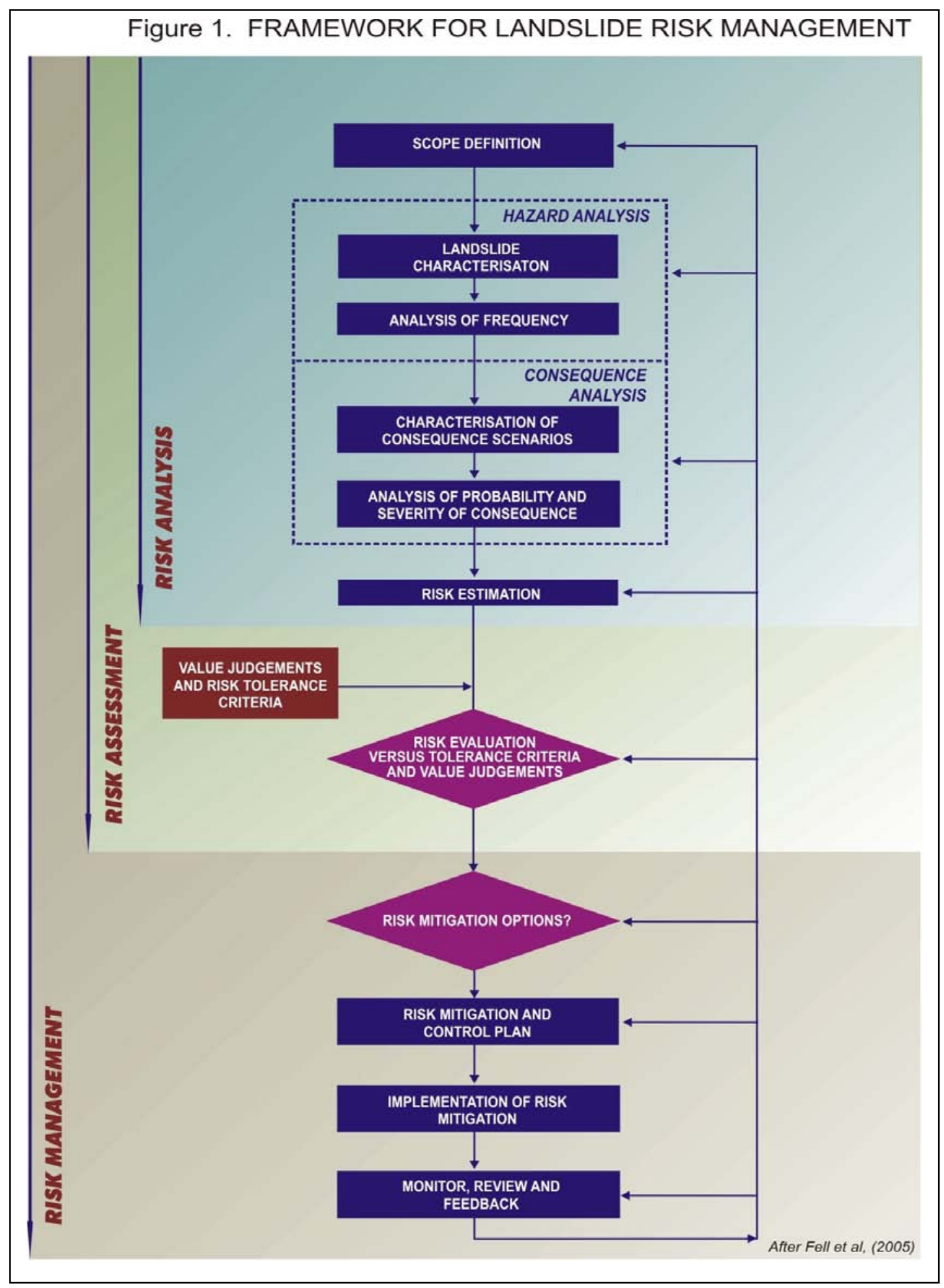
ZONING FOR LAND USE PLANNING

4.1 TYPES OF LANDSLIDE ZONING

Landslide Susceptibility Zoning involves the classification, volume (or area) and spatial distribution of existing and potential landslides in the study area. It may also include a description of the travel distance, velocity and intensity of the existing or potential landsliding. Landslide susceptibility zoning usually involves developing an inventory of landslides which have occurred in the past together with an assessment of the areas with a 
potential to experience landsliding in the future, but with no assessment of the frequency (annual probability) of the occurrence of landslides. In some situations susceptibility zoning will need to be extended outside the study area being zoned for hazard and risk to cover areas from which landslides may travel on to or regress into the area being zoned. It will generally be necessary to prepare separate susceptibility zoning maps to show landslide sources and areas onto which landslides from the source landslides may travel or regress.

Landslide Hazard Zoning takes the outcomes of landslide susceptibility mapping, and assigns an estimated frequency (annual probability) to the potential landslides. It should consider all landsliding which can affect the study area including landslides which are above the study area but may travel onto it and landslides below the study area which may retrogressively fail up-slope into it. The hazard may be expressed as the frequency of a particular type of landslide of a certain volume or landslides of a particular type, volume and velocity (which may vary with distance from the landslide source) or, in some cases, as the frequency of landslides with a particular intensity where intensity may be measures in kinetic energy terms. Intensity measures are most useful for rock falls.

Landslide Risk Zoning takes the outcomes of hazard mapping and assesses the potential damage to persons (annual probability the person most at risk loses his or her life) and to property (annual value of property loss) for the elements at risk, accounting for temporal and spatial probability and vulnerability.

It will often be necessary to produce separate susceptibility, hazard and risk zoning maps for the different types of landslides affecting the area; e.g. for rock falls, small shallow landslides and deep-seated larger landslides. It may be necessary to produce separate maps for landslides from natural slopes and constructed slopes. If these are combined on to one map the boundaries may be confusing.

Appendix A in the Commentary has examples of landslide susceptibility, hazard and risk zoning for slopes which may experience rock falls, small landslides and large landslides.

\section{GUIDANCE ON WHERE LANDSLIDE ZONING IS USEFUL FOR LAND USE} PLANNING

\subsection{GENERAL PRINCIPLES}

Landslide zoning for land use planning is most commonly required the local government level for planning urban development, but may be required by state or federal governments for regional land use planning or disaster management planning. It may also be required by land developers, those managing recreational areas or those developing major infrastructure such as highways and railways. The following are some examples of situations that are more susceptible to landslide occurrence. Their identification through landslide zoning would facilitate development planning and landslide risk management. It is the combination of having an area which is potentially subject to landsliding and the scale and type of development of the area that will determine whether landslide zoning is needed for land use planning. The type of zoning required is discussed in Section 6.

\subsection{TOPOGRAPHICAL, GEOLOGICAL AND DEVELOPMENT SITUATIONS WHERE LANDSLIDING IS POTENTIALLY AN ISSUE}

The following are examples where landsliding is potentially an issue in land use planning:

(a) Where there is a history of landsliding e.g:

- $\quad$ Deep-seated sliding on natural slopes.

- Widespread shallow slides on steep natural slopes.

- $\quad$ Rock falls from steep slopes and cliffs.

- $\quad$ Rock falls from coastal cliffs.

- $\quad$ Landslides in cuts, fills and retaining walls on roads, railways and associated with urban development.

- Large currently inactive landslides subject to undercutting by active erosion of the toe or subject to reactivation by development.

- $\quad$ Debris flows and earth slides from previously failed slopes.

- Widespread shallow creep type landslides in slopes of any inclination.

(b) Where there is no history of sliding but the topography dictates sliding may occur. e.g:

- Cliffs (coastal and inland).

- $\quad$ Natural slopes steeper than $35^{\circ}$ (landslide travel is likely to be rapid).

- Natural slopes between $20^{\circ}$ and $35^{\circ}$ (rapid landslide travel is possible).

- $\quad$ Steep, high road or rail cuttings.

- $\quad$ Steep slopes degraded by recent forest logging, forest fires and/or construction of roads. 


\section{GUIDELINE FOR LANDSLIDE SUSCEPTIBILITY, HAZARD AND RISK ZONING}

- $\quad$ Large currently inactive landslides subject to rising groundwater regimes; e.g. by forestry and agricultural operations.

(c) When there is no history of sliding but geological and geomorphologic conditions are such that sliding is possible e.g:

- Weathered basalt overlying other more competent rocks (sliding often occurs on the boundaries).

- Weathered granitic and volcanic rocks.

- Weathered interbedded rocks (such as claystone, shale and siltstone) and sandstone or limestone.

- Sand dunes.

- $\quad$ River banks in soil subject to floods and/or active erosion.

- $\quad$ Steep natural slopes in regions affected by large earthquakes.

- $\quad$ Slopes in highly sensitive weak clays (e.g. quick clays).

- Where there is active undercutting of slopes by rivers or the sea.

- In seismically active regions slopes in loose saturated soil which are susceptible to liquefaction.

(d) Where there are constructed features which, should they fail, may travel rapidly e.g:

- $\quad$ Loose silty sandy fills (residual/extremely weathered granite; ripped sandstone etc).

- $\quad$ Other side cast fills on steep slopes.

- $\quad$ Large retaining walls.

- $\quad$ Mine overburden spoil and mine waste dumps, particularly those sited on hillsides.

- Tailings dams constructed using upstream construction methods.

(e) Forestry works and agricultural land clearing where landsliding may lead to damage to the environment by degrading streams and other receiving water bodies.

It should be noted that rapid sliding is important because of the potential for life loss. However slow and very slow moving landslides are also of importance because they may also lead to property damage.

\subsection{TYPES OF DEVELOPMENT WHERE LANDSLIDE ZONING FOR LAND USE PLANNING WILL} BE BENEFICIAL

The following are examples of where landslide zoning for land use planning will be beneficial:

(a) Residential land development

- New urban areas.

- Subdivision of rural land.

- Subdivision of urban land where a number of allotments will be formed. It is envisaged that an area of at least 2 hectares or 20 house allotments would be involved. For smaller areas the procedures for individual risk assessments can be followed.

- Redevelopment of urban areas.

(b) Residential development controls in existing urban areas potentially affected by landsliding.

- Within part or all of a local government area.

- City wide.

(c) Development of important infrastructure.

- Hospitals, schools, fire brigades and other emergency services.

- Critical communications infrastructure.

- $\quad$ Major lifelines such as transport, water, gas pipelines and electricity power lines

(d) Recreational areas.

- Alpine resorts.

- $\quad$ Other resorts e.g. islands.

- $\quad$ State and national parks (coastal and others).

- $\quad$ Sports facilities.

- Coastal walkways.

(e) Development of new or redevelopment of existing highways, roads and railways.

- Rural.

- Urban main roads.

- Urban subdivision roads.

(f) Public land where landsliding may travel on to or retrogress into adjacent developments.

- $\quad$ State forests.

- $\quad$ State and National parks.

- Municipal parks. 


\section{GUIDELINE FOR LANDSLIDE SUSCEPTIBILITY, HAZARD AND RISK ZONING}

(g) River valleys in which dams are to be constructed, including the slopes adjoining the reservoir and river valleys upstream where there is potential for blockage of rivers by landslides and breach of the landslide dam with subsequent outburst floods, and/or the creation of large waves which may overtop the dam if a large rapidly moving landslide travels into the reservoir.

It should be recognized that if the land under consideration for land use planning falls into any of the categories in Section 5.2, there will be potential land management benefits in carrying out landslide zoning.

The categories listed are not meant to be a complete list. Nether is it meant that if one or more of these categories are present that landslide zoning is essential. Those involved should assess whether zoning is necessary taking account of the factors detailed above, the development proposed and the applicable regulatory requirements.

\section{SELECTION OF THE TYPE AND LEVEL OF LANDSLIDE ZONING}

\subsection{SOME GENERAL PRINCIPLES}

Landslide zoning is carried out for regional, local and site specific planning. The outputs are usually in the form of one or more of the following: landslide inventory, susceptibility, hazard and risk zoning maps and associated reports.

The type and level of detail of the zoning and the scale of the maps depends on the purpose to which the landslide zoning is to be applied and a number of other factors:

- The stage of development of the land use zoning plan or engineering project. Susceptibility and hazard zoning are more likely to be used in preliminary stages of development with hazard and risk zoning for more detailed stages. However the choice depends mostly on the intended purpose of the zoning in land use management.

- The type of development. Risk zoning is more likely to be used for existing urban developments where the elements at risk are defined or for existing and planned road and railway developments where the elements at risk (the road or rail users) are readily predicted. However, the elements at risk often vary with time so risk zoning needs to be up-dated regularly.

- The classification, activity, volume or intensity of landsliding. Risk zoning is more likely to be required where the landslides are likely to travel rapidly and or have a high intensity as measured by the combination of volume and velocity (e.g. rock fall, debris flows, rock avalanches). For these situations life loss is more likely so it is useful to use risk zoning as this allows land use zoning to be determined using life loss risk criteria.

- Funds available. While the purpose should determine the level of zoning and the scale of the maps, the funding available may be a practical constraint. Landslide susceptibility zoning is lower cost than hazard zoning, and hazard zoning is somewhat lower cost than risk zoning, so land use planners may opt for a lesser type and level of mapping at least in a staged introduction of landslide land use planning.

- The amount and quality of available information. Only susceptibility zoning is performed where data on frequency of landslides either do not exist or are so uncertain as to not be relied on.

- History of land use. The history of the area being zoned and its evolution in terms of land use must be carefully taken into account as human activities may modify the slope instability environment and modify the susceptibility to and likelihood of landsliding and hence the hazard.

- Degree of quantification. Qualitative methods are often used for susceptibility zoning and sometimes for hazard zoning. It is better to use quantitative methods for both susceptibility and hazard zoning. Risk zoning should be quantified. More effort is required to quantify the hazard and risk but there is not necessarily a great increase in cost compared to qualitative zoning.

- The required accuracy of the zoning boundaries. Where statutory land use planning constraints are proposed large scale maps with appropriate levels of inputs should be used. In this regard it should be noted that State and Local governments may have different requirements. The largest scale required will determine the level and scale of landslide zoning.

- Linkage to the proposed planning controls. The use of complementary or linking processes such as planning schedules and development control plans whereby the landslide zoning initiates a more detailed assessment at site scale. In this case, the use of landslide susceptibility mapping which defines a planning control area may be sufficient to identify where a more detailed landslide risk assessment is needed. 


\section{GUIDELINE FOR LANDSLIDE SUSCEPTIBILITY, HAZARD AND RISK ZONING}

Table 1: Recommended types and levels of zoning and zoning map scales related to landslide zoning purpose.

\begin{tabular}{|c|c|c|c|c|c|c|c|c|}
\hline \multirow[t]{2}{*}{ Purpose } & \multicolumn{4}{|c|}{ Type of Zoning } & \multicolumn{3}{|c|}{ Zoning Level } & \multirow{2}{*}{$\begin{array}{c}\text { Applicable } \\
\text { Zoning } \\
\text { Map Scales }\end{array}$} \\
\hline & Inventory & Susceptibility & Hazard & Risk & Preliminary & Intermediate & Advanced & \\
\hline \multicolumn{9}{|c|}{ Regional Zoning } \\
\hline Information & $\mathrm{X}$ & $\mathrm{X}$ & & & $\mathrm{X}$ & & & $1: 25,000$ \\
\hline Advisory & $\mathrm{X}$ & $\mathrm{X}$ & $(\mathrm{X})$ & & $\mathrm{X}$ & $(\mathrm{X})$ & & to \\
\hline Statutory & \multicolumn{7}{|c|}{ NOT RECOMMENDED } & $1: 250,000$ \\
\hline
\end{tabular}

Local Zoning

\begin{tabular}{|c|c|c|c|c|c|c|c|c|}
\hline Information & $\mathrm{X}$ & $\mathrm{X}$ & $\mathrm{X}$ & $(\mathrm{X})$ & $\mathrm{X}$ & $(\mathrm{X})$ & $\mathrm{X}$ \\
\hline Advisory & $(\mathrm{X})$ & $\mathrm{X}$ & $\mathrm{X}$ & $\mathrm{X}$ & $\mathrm{X}$ & $\mathrm{X}$ \\
\hline Statutory & & $(\mathrm{X})$ & $\mathrm{X}$ & $(\mathrm{X})$ & & $\mathrm{X}$ & $\mathrm{X}$ \\
\hline
\end{tabular}

Site Specific Zoning

\begin{tabular}{|c|c|c|c|c|c|c|}
\hline \multicolumn{6}{|c|}{ NOT RECOMMENDED } & \multirow{3}{*}{$\begin{array}{c}>1: 5000, \\
\text { typically } \\
1: 5,000\end{array}$} \\
\hline Advisory & & & $\mathrm{MOI}$ & & & \\
\hline Statutory & $(\mathrm{X})$ & $\mathrm{X}$ & $\mathrm{X}$ & $\mathrm{X}$ & $\mathrm{X}$ & \\
\hline Design & $(\mathrm{X})$ & $(\mathrm{X})$ & $\mathrm{X}$ & $(\mathrm{X})$ & $\mathrm{X}$ & $\begin{array}{c}\text { to } \\
1: 1,000\end{array}$ \\
\hline
\end{tabular}

Notes: $\mathrm{X}=$ applicable; $(\mathrm{X})$ = may be applicable 


\section{GUIDELINE FOR LANDSLIDE SUSCEPTIBILITY, HAZARD AND RISK ZONING}

\section{2}

\section{RECOMMENDED TYPES AND LEVELS OF ZONING AND MAP SCALES}

Table 1 shows the recommended types of zoning, zoning levels and mapping scales that depend on the purpose of the zoning. The table is applicable to land use planning for urban development. The table is broadly applicable to other uses such as managing landslide hazard and risks for new and existing roads and railways.

It will usually be appropriate to carry out landslide susceptibility zoning as a first stage in the development of landslide hazard or risk zoning for planning purposes. Staging will allow better control of the process and may reduce the costs of the zoning by limiting the more detailed zoning only to areas where it is necessary.

It should be noted that it will seldom be necessary to carry out landslide zoning at an advanced level because the costs will potentially be so much larger than the costs for intermediate level zoning and this will potentially outweigh the benefits.

The levels of zoning and descriptors of susceptibility, hazard and risk are given in the following sections. It is recommended that these descriptors be used by all involved in landslide risk management.

\subsection{DEFINITION OF THE LEVELS OF ZONING}

Table 2 defines the levels of landslide inventory, susceptibility, hazard and risk zoning in terms of geotechnical and other input data. The definitions of the levels of the input data are given in Section 8. It is important to match the level of the zoning to the required usage, the scale of mapping and in turn match these to the level of the input data. It is not possible, for example, to produce a satisfactory advanced level hazard zoning without at least intermediate level assessment of frequency of landsliding. If only a basic level assessment of frequency can be made then the result will be no better than preliminary level and there is no point spending large resources getting the other inputs to a intermediate or, in particular, to a sophisticated level. On the other hand, if a preliminary level hazard zoning is required then the inputs may be at the basic level.

Table 2: Levels of activity required for susceptibility, hazard and risk zoning levels.

\begin{tabular}{|c|c|c|c|c|c|c|c|}
\hline \multirow{4}{*}{$\begin{array}{c}\text { Type } \\
\text { of } \\
\text { Zoning }\end{array}$} & \multicolumn{7}{|c|}{ Risk Zoning } \\
\hline & \multicolumn{4}{|c|}{ Hazard Zoning } & & & \\
\hline & \multicolumn{3}{|c|}{ Susceptibility Zoning } & & & & \\
\hline & $\begin{array}{c}\text { Inventory } \\
\text { Mapping } \\
\end{array}$ & & & & & & \\
\hline Zoning Level & $\begin{array}{c}\text { Inventory of } \\
\text { existing } \\
\text { landslides }\end{array}$ & $\begin{array}{c}\text { Characteriz- } \\
\text { ation of } \\
\text { potential } \\
\text { landslides } \\
\end{array}$ & $\begin{array}{l}\text { Travel distance } \\
\text { and velocity }\end{array}$ & $\begin{array}{l}\text { Frequency } \\
\text { assessment }\end{array}$ & $\begin{array}{c}\text { Temporal } \\
\text { spatial } \\
\text { probability }\end{array}$ & Elements at risk & Vulnerability \\
\hline Preliminary & Basic $^{(1)(2)}$ & Basic $^{(1)(2)}$ & $\begin{array}{l}\text { Basic } \\
\text { Intermediate } \\
\quad(2)\end{array}$ & Basic $^{(1,2)}$ & Basic $^{(1,2)}$ & $\operatorname{Basic}^{(1,2)}$ & Basic $^{(1,2)}$ \\
\hline Intermediate & Intermediate & Intermediate & Intermediate & Intermediate & Intermediate & Intermediate & $\begin{array}{c}\text { Intermediate to } \\
\text { Basic }\end{array}$ \\
\hline Advanced & Sophisticated & $\begin{array}{l}\text { Sophisticated } \\
\text { to } \\
\text { Intermediate }\end{array}$ & $\begin{array}{l}\text { Intermediate to } \\
\text { Sophisticated }\end{array}$ & $\begin{array}{l}\text { Intermediate } \\
\text { to } \\
\text { Sophisticated }\end{array}$ & Sophisticated & Sophisticated & $\begin{array}{c}\text { Intermediate to } \\
\text { Sophisticated }\end{array}$ \\
\hline
\end{tabular}

Notes:

(1) For qualitative zoning

(2) For quantitative zoning

(3) See Section 8 for description of the levels of input information. viz basic, intermediate, sophisticated.

\subsection{LANDSLIDE ZONING REPORTS}

Landslide zoning reports should include:

- A landslide inventory map and associated information on landslides in the inventory such as classification, location, time of sliding (if known), volume and a description of validation and limitations of the inventory. 
- Susceptibility zoning map(s) with related information on how susceptibility was determined and a description of validation and limitations of the zoning.

- Where hazard zoning is required a hazard zoning map(s) at an appropriate scale with related information on how frequency of landsliding was assessed and a description of validation and limitations of the zoning. The report should also include the landslide inventory and susceptibility zoning.

Where risk zoning is required a risk zoning map(s) at an appropriate scale with related information on how frequency of landsliding was assessed and detail the assumed elements at risk, temporal spatial probabilities and vulnerabilities and how these were determined and a description of validation and limitations of the zoning. The report should also include the landslide inventory and susceptibility and hazard zoning.

\section{LANDSLIDE ZONING MAP SCALES AND DESCRIPTORS FOR SUSCEPTIBILITY, HAZARD AND RISK ZONING}

\subsection{SCALES FOR LANDSLIDE ZONING MAPS AND THEIR APPLICATION}

Table 3 summarizes map scales and the landslide inventory, susceptibility, hazard and risk mapping to which they are usually applied. Landslide zoning maps should be prepared at a scale appropriate for displaying the information needed at a particular zoning level.

Table 3: Landslide zoning mapping scales and their application.

\begin{tabular}{|c|c|l|c|}
\hline Scale Description & $\begin{array}{c}\text { Indicative Range of } \\
\text { Scales }\end{array}$ & \multicolumn{1}{|c|}{ Examples of Zoning Application } & $\begin{array}{c}\text { Typical Area of } \\
\text { Zoning }\end{array}$ \\
\hline Small & $<1: 100,000$ & $\begin{array}{l}\text { Landslide inventory and susceptibility to inform } \\
\text { policy makers and the general public }\end{array}$ & $\begin{array}{l}>10,000 \\
\text { kilometres }\end{array}$ \\
\hline Medium & $\begin{array}{c}1: 100,000 \\
\text { to } \\
1: 25,000\end{array}$ & $\begin{array}{l}\text { Landslide inventory and susceptibility zoning } \\
\text { for regional and local development or very large } \\
\text { scale engineering projects. } \\
\text { Preliminary level hazard mapping for local areas }\end{array}$ & $\begin{array}{c}1000-10,000 \text { square } \\
\text { kilometres }\end{array}$ \\
\hline Large & $\begin{array}{l}\text { Landslide inventory, susceptibility and hazard } \\
\text { zoning for local areas } \\
\text { Preliminary level risk zoning for local areas and } \\
\text { the advanced stages of planning for large } \\
\text { engineering structures, roads and railways }\end{array}$ & $\begin{array}{c}10-1000 \text { square } \\
\text { kilometres }\end{array}$ \\
\hline Detailed & $\begin{array}{l}\text { Intermediate and advanced level hazard and risk } \\
\text { zoning for local and site specific areas and for } \\
\text { the design phase of large engineering structures, } \\
\text { roads and railways }\end{array}$ & $\begin{array}{c}\text { Several hectares to } \\
\text { tens of square } \\
\text { kilometres }\end{array}$ \\
\hline
\end{tabular}

In practical terms the scale of mapping may be controlled by the scale of the available topographic maps.

\subsection{DESCRIPTORS OF THE DEGREE OF SUSCEPTIBILITY, HAZARD AND RISK FOR USE IN LANDSLIDE ZONING}

\subsubsection{General}

There will be considerable benefits if those carrying out landslide zoning use common descriptors to describe the degree of landslide susceptibility, hazard and risk. It will allow geotechnical professionals doing the zoning to relate to each other and allow legislators and those developing building controls to refer to these descriptors in the knowledge that they have a uniform meaning. This Section defines susceptibility, hazard and risk descriptors.

\subsubsection{Examples of landslide susceptibility descriptors}

It is difficult to standardise descriptions of landslide susceptibility because:

- Whether the geological, topographical, geotechnical and climatic conditions are judged to be conducive to landsliding is often subjective and not readily quantified.

- Different descriptors are required for the different types of landslides, e.g. the proportion of the area which may be affected by the landsliding for small scale landslides; the number of landslides/ square $\mathrm{km}$ for small landslides; the number of rock falls per kilometre length of cliff etc. 
- The difficulty of assessing whether if landsliding occurs, it will travel on to slopes below or retrogress up-slope and the likelihood that a particular area will be affected by the landslide.

- The time frame in which landslides have occurred is not included (it is in hazard)

In some situations it may be sufficient to simply use two susceptibility descriptors; "susceptible" and "not susceptible". In general however there will be value in conveying to users of the maps the degrees of susceptibility either in quantified or relative terms.

Table 4 gives examples of landslide susceptibility mapping descriptors for some more common scenarios.

Table 4: Examples of landslide susceptibility mapping descriptors.

\begin{tabular}{|l|c|c|c|}
\hline $\begin{array}{l}\text { Susceptibility } \\
\text { Descriptors }\end{array}$ & Rock Falls & $\begin{array}{c}\text { Small Landslides on } \\
\text { Natural Slopes }\end{array}$ & $\begin{array}{c}\text { Large Landslides on } \\
\text { Natural Slopes }\end{array}$ \\
\hline
\end{tabular}

\section{(a) Quantified susceptibility descriptors}

\begin{tabular}{|l|c|c|c|}
\hline & $\begin{array}{l}\text { Probability rock falls } \\
\text { will reach the area given } \\
\text { rock falls occur from a } \\
\text { cliff }\end{array}$ & $\begin{array}{l}\text { Proportion of area in } \\
\text { which small landslides } \\
\text { may occur }\end{array}$ & $\begin{array}{l}\text { Proportion of area in } \\
\text { which large landslides } \\
\text { may occur }\end{array}$ \\
\hline High susceptibility & $>0.5$ & $>0.5$ & $>0.5$ \\
\hline $\begin{array}{l}\text { Moderate } \\
\text { Susceptibility }\end{array}$ & $>0.25$ to 0.5 & $>0.25$ to 0.5 & $>0.25$ to 0.5 \\
\hline Low susceptibility & $>0.01$ to 0.25 & $>0.01$ to 0.25 & $>0.01$ to 0.25 \\
\hline Very low susceptibility & 0 to 0.01 & 0 to 0.01 & 0 to 0.01 \\
\hline
\end{tabular}

(b) Relative susceptibility descriptors

\begin{tabular}{|l|c|c|c|}
\hline $\begin{array}{l}\text { Susceptibility } \\
\text { Descriptors }\end{array}$ & Rock Falls & $\begin{array}{l}\text { Small Landslides on } \\
\text { Natural Slopes }\end{array}$ & $\begin{array}{l}\text { Large Landslides on } \\
\text { Natural Slopes }\end{array}$ \\
\hline & $\begin{array}{l}\text { The proportion of the total } \\
\text { landslide population in the } \\
\text { study area. }\end{array}$ & $\begin{array}{l}\text { The proportion of the total } \\
\text { landslide population in the } \\
\text { study area. }\end{array}$ & $\begin{array}{l}\text { The proportion of the total } \\
\text { landslide population in the } \\
\text { study area. }\end{array}$ \\
\hline High susceptibility & $>0.5$ & $>0.5$ & $>0.5$ \\
\hline Moderate Susceptibility & $>0.1$ to 0.5 & $>0.1$ to 0.5 & $>0.1$ to 0.5 \\
\hline Low susceptibility & $>0.01$ to 0.1 & $>0.01$ to 0.1 & $>0.01$ to 0.1 \\
\hline Very low susceptibility & 0 to 0.01 & 0 to 0.01 & 0 to 0.01 \\
\hline
\end{tabular}

Notes

(1) Spatial probability determined from historic, relative stability indexes, data or analysis taking consideration of the uncertainty in travel distance.

(2) Based on landslide inventory, geology, topography and geomorphology.

(3) Usually this is active, dormant and potentially reactivated slides, not first time slides.

(4) By "small” landslides is meant here landslides which are less than about $1000 \mathrm{~m}^{3}$ volume.

Rock fall susceptibility may also be described in terms of the density of scars on a rock slope from which falls have occurred or the number of rocks which have fallen from a slope. For small shallow landslides the susceptibility may also be expressed as the number of slides per square kilometre.

There are advantages in using the quantified susceptibility descriptors in that the susceptibility of different areas being zoned can be compared. Relative susceptibility applies only within the study area and may represent quite different absolute susceptibilities in different areas being zoned.

For the relative susceptibility descriptors the objective usually is to include the largest number of landslides in the higher susceptibility classes whilst trying to achieve the minimum spatial area for these classes. So the higher susceptibility classes should have the greatest density of landslides, even though the density is not assessed.

It is important to note that landslide susceptibility mapping does not quantify the number of rock falls or small landslides which may occur in a given time period, nor for large landslides the annual probability that landsliding will occur. That is done in hazard mapping.

\subsubsection{Recommended landslide hazard zoning descriptors}

The manner in which landslide hazard is described depends on the type of landslide. For small slides and rock falls the hazard is described in terms of the number of slides per length of source area/annum, or the number of landslides per square kilometre of source area/annum. For large landslides hazard is described in terms of the annual probability of active sliding, or for active slides the annual probability movement will exceed a defined distance or the annual 
probability that cracking within a slide exceeds a defined length. Table 5 presents recommended descriptors for the most common landslide and rock fall situations.

Table 5: Recommended descriptors for hazard zoning.

\begin{tabular}{|l|c|c|c|c|}
\hline $\begin{array}{l}\text { Hazard } \\
\text { Descriptor }\end{array}$ & $\begin{array}{c}\text { Rock Falls from } \\
\text { Natural Cliffs or Rock } \\
\text { Cut Slope }\end{array}$ & $\begin{array}{c}\text { Slides of Cuts and } \\
\text { Fills on Roads or } \\
\text { Railways }\end{array}$ & $\begin{array}{c}\text { Small Landslides } \\
\text { on Natural Slopes }\end{array}$ & $\begin{array}{c}\text { Individual } \\
\text { Landslides on } \\
\text { Natural Slopes }\end{array}$ \\
\hline Very High & $\begin{array}{c}\text { Number/annum/km of } \\
\text { cliff or rock cut slope }\end{array}$ & $\begin{array}{c}\text { Number/annum/km } \\
\text { of cut or fill }\end{array}$ & $\begin{array}{c}\text { Number/square } \\
\text { km/annum }\end{array}$ & $\begin{array}{c}\text { Annual probability } \\
\text { of active sliding }\end{array}$ \\
\hline High & $>10$ & $>10$ & $>10$ & $10^{-1}$ \\
\hline Moderate & 1 to 10 & 1 to 10 & 1 to 10 & $10^{-2}$ \\
\hline Low & 0.1 to 1 & 0.1 to 1 & 0.1 to 1 & $10^{-3}{\text { to } 10^{-4}}^{-5}$ \\
\hline Very Low & 0.01 to 0.1 & 0.01 to 0.1 & 0.01 to 0.1 & $10^{-5}$ \\
\hline
\end{tabular}

The description of the hazard should include the classification and volume (or area) of the landslides.

\subsubsection{Recommended landslide risk zoning descriptors}

Table 6 gives recommended descriptors for landslide risk zoning using life loss criteria. These are based on annual individual risk for the person most at risk.

If there is a potential for a large number of persons to be killed in one landslide event there should be an assessment of societal risk as described in AGS (2007c) and Leroi et al. (2005).

For property loss risks the risk matrix and terms in AGS (2007c) should be used. This is reproduced in Table 7.

It should be recognised that risk zones are dependent on the hazard, the elements at risk and risk control factors. If any of these alter the risk zoning will need to be revised.

Table 6: Recommended descriptors for risk zoning using life loss criteria.

\begin{tabular}{|l|l|}
\hline $\begin{array}{l}\text { Annual Probability of Death of } \\
\text { the Person Most at Risk in the } \\
\text { Zone }\end{array}$ & $\begin{array}{l}\text { Risk Zoning } \\
\text { Descriptors }\end{array}$ \\
\hline$>10^{-3}$ /annum & Very High \\
\hline $10^{-4}$ to $10^{-3} /$ annum & High \\
\hline $10^{-5}$ to $10^{-4}$ /annum & Moderate \\
\hline $10^{-6}$ to $10^{-5}$ /annum & Low \\
\hline$<10^{-6} /$ annum & Very Low \\
\hline
\end{tabular}

Table 7: Recommended descriptors for risk zoning using property loss criteria (AGS 2007c).

\begin{tabular}{|c|c|c|c|c|c|c|}
\hline \multicolumn{2}{|c|}{ Likelihood } & \multicolumn{5}{|c|}{ Consequences to property (With indicative approximate cost of damage) ${ }^{(1)}$} \\
\hline & $\begin{array}{c}\text { Indicative } \\
\text { Value of } \\
\text { Approximate } \\
\text { Annual } \\
\text { Probability }\end{array}$ & $\begin{array}{c}\text { 1: } \\
\text { CATASTROPHIC } \\
200 \%\end{array}$ & $\begin{array}{c}\text { 2: } \\
\text { MAJOR } \\
60 \%\end{array}$ & $\begin{array}{c}\text { 3: } \\
\text { MEDIUM } \\
20 \%\end{array}$ & $\begin{array}{c}\text { 4: } \\
\text { MINOR } \\
5 \%\end{array}$ & $\begin{array}{c}\text { 5: } \\
\text { INSIGNIFICANT } \\
0.5 \%\end{array}$ \\
\hline $\begin{array}{l}\text { A ALMOST } \\
\text { CERTAIN }\end{array}$ & $10^{-1}$ & $\mathrm{VH}$ & $\mathrm{VH}$ & $\mathrm{VH}$ & $\mathrm{H}$ & $\mathbf{M}$ or $\mathbf{L}^{(2)}$ \\
\hline B LIKELY & $10^{-2}$ & $\mathrm{VH}$ & $\mathrm{VH}$ & $\mathrm{H}$ & $\mathrm{M}$ & $\mathbf{L}$ \\
\hline C -POSSIBLE & $10^{-3}$ & $\mathrm{VH}$ & $\mathrm{H}$ & $\mathrm{M}$ & $\mathrm{M}$ & VL \\
\hline $\begin{array}{ll}\text { D } & \text { UNLIKELY }\end{array}$ & $10^{-4}$ & $\mathrm{H}$ & $M$ & $\mathbf{L}$ & $\mathbf{L}$ & VL \\
\hline E $\quad$ RARE & $10^{-5}$ & M & $\mathbf{L}$ & $\mathbf{L}$ & VL & VL \\
\hline $\begin{array}{l}\text { F BARELY } \\
\text { CREDIBLE }\end{array}$ & $10^{-6}$ & L & VL & VL & VL & VL \\
\hline
\end{tabular}

Notes: (1) As a percentage of the value of the property.

(2) For Cell A5, may be subdivided such that a consequence of less than $0.1 \%$ is Low Risk.

(3) L low, M medium, H high, VL very low, VH very high. 


\section{GUIDELINE FOR LANDSLIDE SUSCEPTIBILITY, HAZARD AND RISK ZONING}

\subsubsection{Recommended approach}

It is recommended that Table 6 be used universally for life loss risk zoning. It is suggested that Table 7 be used for property loss so far as is practicable but it is recognized that project specific terms may be developed.

It is suggested that so far as possible Tables 4 and 5 be used to describe susceptibility and hazard zoning, but it is recognised that there will be cases where site specific descriptors will be preferred. Whatever descriptors are used it is important that the definitions should be attached to the report and so far as practical shown on zoning maps. Landslide zoning will generally be done for conditions as they are at the time of the study. There may be situations where a second zoning may be presented to allow for hazard and risk management measures which may be proposed as part of a land development.

\section{$8 \quad$ METHODS FOR LANDSLIDE ZONING FOR LAND USE PLANNING}

\subsection{THE PURPOSE OF THIS SECTION}

This Section discusses the methods for landslide zoning for land use planning. It is based on Table 1 which lists the levels of susceptibility, hazard and risk zoning, how these are related to the methods used to assess the inputs to the zoning and whether the inputs are determined using basic, intermediate or sophisticated methods. The methods involve "activities" which are presented so there is a common understanding of what is involved in the zoning process.

\subsection{THE IMPORTANCE OF UNDERSTANDING SLOPE PROCESSES AND THE GEOTECHNICAL CHARACTERISTICS OF THE LANDSLIDING}

It is essential for all levels of landslide inventories and susceptibility, hazard and risk zoning that those carrying out the study have a detailed knowledge of slope processes which lead to landslides. This includes knowledge of geology, geomorphology, and hydrogeology and the soil and rock mechanics of landsliding. It is also essential that there is sufficient geotechnical information about the slopes to allow an understanding of the soil and rock mechanics of slope failure. Zoning done in the absence of this knowledge is almost certain to be misleading.

\subsection{APPLICATION OF GIS-BASED TECHNIQUES TO LANDSLIDE ZONING}

It is strongly recommended that landslide zoning be carried out in a GIS-based system so that the zoning can be readily be applied for land use planning and can be up-dated as more information becomes available.

A Geographic Information System (GIS) is a computer-based system which facilitates the acquisition, storage, management, analysis and display of geographic data. GIS typically includes relational database functionality incorporating spatial data attributes, but also includes the ability to spatially manipulate and present the data with elaborate mapping capabilities and powerful spatial analyses.

The essential feature of all GIS platforms is that they recognize the spatial attributes of the data presented allowing natural features to be treated as part of a spatial system, rather than an isolated object. This capability enables the spatial system, (i.e., the environment of any given region) to be built within the computer project environment using often disparate data sets. The data used in this process can come from a variety of sources, often the project itself (geological and engineering geological mapping, landslide mapping, traditional surveys, GPS surveys, drilling of boreholes, test pits etc) and other outside sources including government organizations and authorities, private companies and other spatial organizations (i.e., digital elevation models, cadastre, contours, aerial photography, land usage, vegetation etc).

One of the most important capabilities of GIS is the ability of the software to manage spatial data, from data collection and generation through to archiving and documentation of data. An important point is that once data is in the GIS, it remains available for editing and updating, for reproduction in the form of maps or on-screen review, manipulation and querying and for GIS-based development and modelling of susceptibility, hazard and risk.

\subsection{LANDSLIDE INVENTORY}

Preparation of a landslide inventory is an essential part of any landslide zoning. It involves the location, classification, volume, travel distance and state of activity and date of occurrence of landsliding in an area. Table 8 lists the activities which will typically be required at the basic, intermediate and sophisticated level. 
Table 8: Activities required to preparing a landslide inventory.

\begin{tabular}{|l|l|}
\hline $\begin{array}{c}\text { Characterisation } \\
\text { Method }\end{array}$ & \multicolumn{1}{c|}{ Activities } \\
\hline \multirow{5}{*}{ Basic } & $\begin{array}{l}\text { Prepare an inventory of landslides in the area from aerial photographs and /or satellite imagery, and by } \\
\text { mapping and from historic records. The inventory includes the location, classification, volume (or area) } \\
\text { and so far as practicable the date of occurrence of landsliding. }\end{array}$ \\
\cline { 2 - 3 } & Identify the relationship to topography, geology and geomorphology. \\
\cline { 2 - 3 } & $\begin{array}{l}\text { Show this information on inventory maps along with topographic information including contours, property } \\
\text { boundaries, mapping grid, roads and other important features such as streams and water-courses. }\end{array}$ \\
\hline \multirow{5}{*}{ Intermediate } & The same activities as Basic plus \\
\cline { 2 - 3 } & Distinguish different parts of the landslides. \\
\cline { 2 - 3 } & Map landslide features and boundaries. \\
\cline { 2 - 3 } & Collect and assess historical information on the activity of landsliding. \\
\cline { 2 - 3 } & $\begin{array}{l}\text { Analyse the past evolution of the land use to know whether human activities have had an influence on the } \\
\text { incidence of landslides. }\end{array}$ \\
\cline { 2 - 3 } & $\begin{array}{l}\text { Increased time and resources in the research phase of the inventory compilation resulting in more rigorous } \\
\text { and extended coverage }\end{array}$ \\
\hline \multirow{5}{*}{ Sophisticated } & The same activities as Intermediate plus \\
\cline { 2 - 3 } & Prepare an inventory of geotechnical data. \\
\cline { 2 - 3 } & Implement investigations to better define geotechnical conditions. \\
\cline { 2 - 3 } & Geotechnical analysis to understand slope instability processes. \\
\cline { 2 - 3 } & $\begin{array}{l}\text { Advanced temporal cataloguing of periodic reactivations of the same hazard and temporal windowing of } \\
\text { specific triggering events to provide periodic inventory data sets which can then be used in advanced } \\
\text { validation approaches. }\end{array}$ \\
\hline
\end{tabular}

\subsection{LANDSLIDE SUSCEPTIBILITY ZONING}

\subsubsection{Landslide characterization and travel distance and velocity}

Landslide susceptibility zoning involves the classification, volume (or area) and spatial distribution of existing and potential landslides in the study area. It may also include a description of the travel distance, velocity and intensity of the existing or potential landsliding.

Table 9: Landslide susceptibility zoning-activities required to characterise, determine the spatial distribution of potential landslides and their relationship to topography, geology and geomorphology.

\begin{tabular}{|c|c|}
\hline $\begin{array}{l}\text { Characterisation } \\
\text { Method }\end{array}$ & Activities \\
\hline \multirow{7}{*}{ Basic } & Prepare a geomorphologic map. ${ }^{(1)}$ \\
\hline & Prepare a landslide inventory as described in Table $8,{ }^{(1)}$ \\
\hline & $\begin{array}{l}\text { Prepare calculations of the \% of the total landslide count for each susceptibility class, the \% of the area } \\
\text { affected by landslides for each class and the \% of each class in comparison to the total study area and } \\
\text { classify according to Table } 4 \text {. }\end{array}$ \\
\hline & $\begin{array}{l}\text { Correlate the incidence of landsliding with the geology and slope to delineate areas susceptible to } \\
\text { landsliding. }\end{array}$ \\
\hline & $\begin{array}{l}\text { For regional zoning correlate the incidence of landsliding with annual rainfall or snowmelt, and/or seismic } \\
\text { loading. }\end{array}$ \\
\hline & Prepare the landslide susceptibility zoning map superimposed on the topography with a suitable legend. \\
\hline & Implement the data and the maps in a GIS (recommended). \\
\hline \multirow{5}{*}{ Intermediate } & The same activities as basic plus \\
\hline & Obtain basic soil classifications and depths in the study area. \\
\hline & $\begin{array}{l}\text { Classify more complex terrain units. Qualitative rating of the landslide susceptible areas based on } \\
\text { overlapping techniques. }\end{array}$ \\
\hline & $\begin{array}{l}\text { Develop quantitative ratings (often relative rating) of landslide susceptible areas based on data treatment } \\
\text { techniques. }\end{array}$ \\
\hline & Implement the data and the maps in a GIS (recommended). \\
\hline \multirow{5}{*}{ Sophisticated } & The same activities as Intermediate plus \\
\hline & $\begin{array}{l}\text { Detailed mapping and geotechnical investigations to develop an understanding of the mechanics of } \\
\text { landsliding, hydrogeology and stability analyses. }\end{array}$ \\
\hline & $\begin{array}{l}\text { Perform data treatment analysis (discriminate; neural networks; fuzzy logic; logistic regression; etc) and } \\
\text { develop quantitative ratings to obtain susceptibility classes. }\end{array}$ \\
\hline & Perform stability analyses. \\
\hline & Implement the data and the maps in a GIS (recommended). \\
\hline
\end{tabular}

Note. (1) The landslide inventory and geomorphologic mapping should be carried out at intermediate and sophisticated levels for intermediate and sophisticated level susceptibility zoning. 


\section{GUIDELINE FOR LANDSLIDE SUSCEPTIBILITY, HAZARD AND RISK ZONING}

Table 9 lists the activities required to characterise the potential landslides, their spatial distribution in the area to be zoned and their relationship to topography, geology and geomorphology. It should be noted that there is a direct relationship between the scale of zoning maps and the level of landslide characterisation, with larger scale zoning maps being required at the intermediate and sophisticated levels. Table 10 lists the activities required to assess the travel distance and velocity of potential landslides. This table is based on the assumption that the activities in Tables 8 and 9 have been carried out.

Table 10: Activities required for assessing the travel distance and velocity of potential landslides.

\begin{tabular}{|c|l|}
\hline $\begin{array}{c}\text { Travel Distance and } \\
\text { Velocity Analysis } \\
\text { method }\end{array}$ & \multicolumn{1}{c|}{ Activities } \\
\hline \multirow{5}{*}{ Basic } & Collect and assess historical information on travel distances and velocity. \\
\cline { 2 - 2 } & $\begin{array}{c}\text { Assess limiting travel distances from geomorphologic data and old landslide } \\
\text { deposits. }\end{array}$ \\
\cline { 2 - 3 } & $\begin{array}{l}\text { Assess the likely travel distance and velocity from consideration of the } \\
\text { classification of the potential landslides, geology and topography and empirical } \\
\text { methods. }\end{array}$ \\
\cline { 2 - 3 } & $\begin{array}{l}\text { Based on this information assess the limit (greatest) likely travel distance for } \\
\text { each classification of potential landslide. }\end{array}$ \\
\hline \multirow{5}{*}{ Intermediate } & The same activities as Basic plus \\
\cline { 2 - 3 } & Assess likely landslide mechanisms and classification of soils in the landslides. \\
\cline { 2 - 3 } & $\begin{array}{l}\text { Use empirical methods based on travel distance angle or shadow angle to } \\
\text { assess travel distance accounting for the uncertainty in the empirical methods } \\
\text { and data inputs. }\end{array}$ \\
\cline { 2 - 3 } & $\begin{array}{l}\text { Assess velocity from potential energy and travel distance using simple sliding } \\
\text { block models. }\end{array}$ \\
\hline \multirow{5}{*}{ Sophisticated } & The same activities as Intermediate plus \\
\cline { 2 - 3 } & $\begin{array}{l}\text { Investigate geotechnical properties of the sliding materials as required by } \\
\text { numerical models. }\end{array}$ \\
\cline { 2 - 3 } & Use numerical models to model travel distance and velocity. \\
\hline
\end{tabular}

\subsubsection{Preparation of landslide susceptibility map}

Preparation of a landslide susceptibility map is usually based on two assumptions:

- That the past is a guide to the future, so that areas which have experienced landsliding in the past are likely to experience landsliding in the future.

- $\quad$ Areas with similar topography, geology and geomorphology as the areas which have experienced landsliding in the past are also likely to experience landsliding in the future.

These assumptions are often reasonable but it should be noted there are exceptions such as when the source of the landslides is exhausted by earlier landsliding.

Landslide susceptibility zoning maps should include:

- A map or a series of maps showing the inventory of historic landslides, showing the location and area (or number of slides, e.g. for rock falls) of the source landslides; where appropriate the travel paths after sliding; or for larger slides the activity or velocity of sliding.

- $\quad$ Maps at the same scale showing the instability conditioning terrain factors: i.e. the topography and topographic units (slope, watershed areas), the geology (lithological units); superficial formations; vegetation cover; land use; etc.

- In areas having potential for shallow landslides and debris flows, it is highly recommended that a map is prepared of the superficial formations (colluvium, till, alluvium, residual soils, etc.) because these types of failures usually take place in these formations. However it must be taken into account that usually these formations are of limited extent so such a map can only be prepared at a large scale.

- Where appropriate prepare a map showing the travel distance limits either as a maximum value or quantified as suggested in Table 10.

- A map showing the interpreted susceptibility zoning classification areas. This map should show the topography and cadastral information as well as the susceptibility zoning classifications for the area being mapped. 
In some cases these may be superimposed on the same zoning map to limit the number of maps but often this will be confusing and it will be necessary to produce separate maps at the same scale for each classification of landslides such as rock falls and small shallow landslides.

\subsection{LANDSLIDE HAZARD ZONING}

\subsubsection{Frequency Assessment}

Tables 11 and 12 list the activities required to assess the frequency of rock falls, slides from cuts, fills and retaining walls, small landslides; and large landslides.

Table 11: Activities required for assessing the frequency of rock falls, slides from cuts, fills and retaining walls and small landslides on natural slopes.

\begin{tabular}{|c|c|}
\hline $\begin{array}{c}\text { Frequency } \\
\text { Assessment Method }\end{array}$ & Activities \\
\hline \multirow{4}{*}{ Basic } & $\begin{array}{l}\text { Frequency established based on the relative freshness of the morphological features of the scars and landside } \\
\text { deposits taking into account the presence of active geomorphic events (e.g. slope undermining by either river or } \\
\text { sea erosion). }\end{array}$ \\
\hline & $\begin{array}{l}\text { Frequency established based on interpretation of numbers of landslides from aerial photographs taken at known } \\
\text { time intervals. }\end{array}$ \\
\hline & $\begin{array}{l}\text { Assess the historic frequency of rock falls, slides from cuts, fills and retaining walls, or small landslides on } \\
\text { natural slopes from basic landslide inventories. }\end{array}$ \\
\hline & As above and relate to the basic level of frequency of triggering events such as daily rainfall or seismic events. \\
\hline \multirow{6}{*}{ Intermediate } & The same activities as Basic plus \\
\hline & $\begin{array}{l}\text { Relate to slope characteristics such as topography (slope angle, elevation, aspect), geology, geomorphology } \\
\text { using multi-variate analyses. }\end{array}$ \\
\hline & $\begin{array}{l}\text { Assess the historic frequency of rock falls, slides from cuts, fills and retaining walls, or small landslides on } \\
\text { natural slopes from landslide inventories. Where appropriate, develop and use frequency volume curves. }\end{array}$ \\
\hline & Use proxy data such as silent witnesses (e.g. damage to trees and dendrochronology). \\
\hline & $\begin{array}{l}\text { More detailed analysis of rainfall including the effects of antecedent rainfall, rainfall intensity and duration on } \\
\text { the incidence of individual landslides (the threshold) or large numbers of landslides. }\end{array}$ \\
\hline & $\begin{array}{l}\text { For seismically induced landsliding, relate the incidence of sliding to seismic loading including the peak } \\
\text { ground acceleration and magnitude of the earthquake using empirical methods. }\end{array}$ \\
\hline \multirow{3}{*}{ Sophisticated } & The same activities as Intermediate plus \\
\hline & $\begin{array}{l}\text { Assess geotechnical parameters of the soils. Model slope factors of safety from geotechnical parameters and } \\
\text { rainfall frequency or piezometric data. }\end{array}$ \\
\hline & $\begin{array}{l}\text { For seismically-induced landslides, analyse displacements using 'Newmark' type analyses and for liquefiable } \\
\text { soils, the likelihood of liquefaction and flow sliding. }\end{array}$ \\
\hline
\end{tabular}

Table 12: Activities required for assessing the frequency of landsliding for large landslides on natural slopes.

\begin{tabular}{|c|l|}
\hline $\begin{array}{c}\text { Frequency } \\
\text { Assessment Method }\end{array}$ & \\
\hline \multirow{4}{*}{ Basic } & $\begin{array}{l}\text { Assess the historic frequency of landsliding from the landslide inventoy including activity indicators such as } \\
\text { cracked buildings, displaced fences, bent and tilted trees. }\end{array}$ \\
\cline { 2 - 3 } & $\begin{array}{l}\text { Assess frequency from geomorphology evidence such as the freshness of slide scarps and other surface features } \\
\text { associated with landslide movement using subjective assessment. }\end{array}$ \\
\hline \multirow{5}{*}{ Intermediate } & The same activities as Basic plus \\
\cline { 2 - 3 } & $\begin{array}{l}\text { As above, and use of proxy data such as carbon 14 dating, lichenometry dating, of vegetation buried by sliding, } \\
\text { or in raised alluvial terraces in valleys which may have been blocked by landsliding. }\end{array}$ \\
\cline { 2 - 3 } & Relate history of landsliding to rainfall intensity and duration and antecedent rainfall or to snow melt. \\
\cline { 2 - 3 } & $\begin{array}{l}\text { Assess the likelihood of seismically-induced sliding from consideration of the mechanics of the landslide. Use } \\
\text { empirical and simplified methods to assess likely displacements during earthquakes. }\end{array}$ \\
\cline { 2 - 3 } & $\begin{array}{l}\text { As an alternative to estimating from historic data, assess frequency by subjective assessment, e.g. by assessing } \\
\text { the probability of landsliding given a rainfall or seismic load. }\end{array}$ \\
\hline \multirow{5}{*}{ Sophisticated } & The same activities as Intermediate plus \\
\cline { 2 - 3 } & $\begin{array}{l}\text { As above and relating the history of landsliding or factor of safety to rainfall, slope geometry, piezometric } \\
\text { levels (where available), geotechnical properties and factors of safety. }\end{array}$ \\
\hline $\begin{array}{l}\text { For seismically-induced landsliding analyse displacements using 'Newmark' type analyses and for liquefiable } \\
\text { soils, the likelihood of liquefaction and flow sliding. }\end{array}$ \\
\hline
\end{tabular}




\section{GUIDELINE FOR LANDSLIDE SUSCEPTIBILITY, HAZARD AND RISK ZONING}

\subsubsection{Intensity assessment}

Landslide intensity may be assessed either as the spatial distribution of:

- The velocity of sliding coupled with slide volume or

- The kinetic energy of the landslide; e.g. rock falls, rock avalanches or

- Total displacement or

- Differential displacement or

- $\quad$ Peak discharge per unit width ( $\left.\mathrm{m}^{3} / \mathrm{m} / \mathrm{second}\right)$, e.g. for debris flows.

The assessment of velocity is discussed in Section 8.5.1. For basic and intermediate level assessments of intensity only velocity and volume might be assessed. For advanced assessments of rock fall and debris flow hazard the energy might be assessed. Whether landslide intensity is required as part of a hazard zoning should be determined on a case-by-case basis. It is likely to be required for rock fall hazard zoning.

\subsubsection{Preparation of Landslide hazard zoning map}

Landslide hazard zoning maps are developed from the susceptibility zoning maps with the areas classified according to the frequency (annual probability) of landsliding. The way the frequency is expressed will depend on the classification and volume of the potential landslides. For example:

- $\quad$ For rock falls the hazard may be expressed as the number of rock falls/annum which will reach the area being mapped per kilometre length along a cliff.

- For slides from cuts, fills and retaining walls the hazard may be expressed as the number of landslides of a certain volume and classification/annum per kilometre of road or per building allotment or per square kilometre.

- $\quad$ For small landslides on natural slopes the hazard may be expressed as the number of landslides of a certain volume, velocity and classification per square $\mathrm{km} /$ annum for the area being mapped

- $\quad$ For large landslides on natural slopes the hazard may be expressed as the annual probability that there will be landsliding in the area being mapped. To this should be added the likely velocity or total displacement of sliding should it occur.

The hazard zoning map should be at the same scale as the susceptibility zoning map and show the topography and cadastral information as well as the hazard zoning classifications for the area being mapped.

\subsection{LANDSLIDE RISK ZONING}

\subsubsection{Elements at risk}

For risk to be determined and hence for landslide risk zoning to be implemented the elements at risk have to be assessed. Table 13 lists the activities required to do this.

The elements at risk include the persons and property potentially affected by landsliding on, below and up-slope of the potential landslides. They may include indirect impacts such as reduced economic activity resulting from the landslide, e.g. due to loss of a road, and environmental impacts.

Table 13: Activities required for assessing the elements at risk.

\begin{tabular}{|c|c|}
\hline $\begin{array}{l}\text { Method for Assessing } \\
\text { Elements at Risk }\end{array}$ & Activity \\
\hline \multirow[t]{2}{*}{ Basic } & $\begin{array}{l}\text { Make an assessment of the population who live, work and travel through the area; } \\
\text { property such as houses, buildings, roads, railways and services which are permanently } \\
\text { in the area and of property such as vehicles which travel through the area. For existing } \\
\text { development base this on the current and proposed land use. For new development } \\
\text { estimate from proposed land use and occupancy. } \\
\text { Where applicable assess environmental values which may be affected by landsliding. }\end{array}$ \\
\hline & $\begin{array}{l}\text { Generic classifications based on the main land uses, namely urban, industrial, } \\
\text { infrastructure, or agricultural. }\end{array}$ \\
\hline Intermediate & As above in greater degree of detail. Economic consequences may be included. \\
\hline Detailed & $\begin{array}{l}\text { As above in detail. Economic consequences will be estimated such as the implications } \\
\text { of loss of a road providing access to a town until repairs are carried out. }\end{array}$ \\
\hline
\end{tabular}




\subsubsection{Temporal spatial probability and vulnerability}

Table 14 lists the activities required to assess the temporal spatial probability of the elements at risk.

Table 14: Activities required for assessing the temporal spatial probability of the elements at risk.

\begin{tabular}{|c|l|}
\hline $\begin{array}{c}\text { Method for assessing } \\
\text { Temporal Spatial } \\
\text { Probability }\end{array}$ & \multicolumn{1}{c|}{ Activity } \\
\hline Basic & $\begin{array}{l}\text { Life Loss Risks } \\
\text { For persons at risk in residential areas assume the temporal-spatial probability is } 1.0 . \\
\text { For other type of developments such as factories and schools, make an approximate } \\
\text { assessment of temporal-spatial probability from the likely pattern of use of the } \\
\text { buildings. } \\
\text { For roads and railways and other situations with transient populations at risk; make } \\
\text { an approximate assessment of temporal spatial probability from the traffic volumes } \\
\text { and velocities. } \\
\text { Property loss risks } \\
\text { For buildings the temporal spatial probability is 1.0. } \\
\text { For vehicles, make an approximate assessment of temporal-spatial probability from } \\
\text { the traffic volumes and velocities. }\end{array}$ \\
\hline Intermediate & $\begin{array}{l}\text { Life Loss Risks } \\
\text { For all situations estimate temporal-spatial probability taking account of the nature } \\
\text { of development, living and work pattern, existence of protected places (e.g. } \\
\text { reinforced shelters), traffic (where relevant) and the intensity of landsliding. } \\
\text { Property loss risks } \\
\text { As for basic assessment although in more detail (e.g. allowing for the variability of } \\
\text { trajectories of rock falls). }\end{array}$ \\
\hline Sophisticated & $\begin{array}{l}\text { As above, with greater detail in the assessment, particularly the temporal/spatial } \\
\text { distribution of the elements at risk. }\end{array}$ \\
\hline
\end{tabular}

Vulnerability is generally assessed empirically for persons and property using published information (e.g. AGS 2007a). More sophisticated methods are not as yet available.

\subsubsection{Preparation of landslide risk zoning maps}

Landslide risk zoning maps are prepared using the hazard zoning maps and allowing for the elements at risk, the spatialtemporal probability and vulnerability. Separate zoning maps will be required for life loss risk and property loss risk. The risk zoning maps should be at the same scale as the susceptibility and hazard zoning maps. They should also show the topography and cadastral information as well as the risk zoning classification of the area.

For life loss, the risk should be expressed as individual risk (annual probability of the person losing his/her life). For property loss, the map may show annualised loss (\$/year) but the report should also list the pairs of loss value and annual probability of the loss (e.g. 0.001 annual probability of $\$ 10$ million loss).

For new development there will have to be an assessment made regarding the proposed development and the elements at risk. The risk will be unique to this proposed development.

If there are several landslide hazards (e.g. rock fall and shallow landslides) the risks are summed to give the total risk. However, it may be useful to present maps showing the risk from each type of landslide, as well as the total risk.

\subsection{THE NEED FOR DOCUMENTATION OF THE LANDSLIDE ZONING PROCESS}

It is essential that the landslide zoning process be well documented in a report. The report should include

- Zoning maps and legends.

- The definitions of the susceptibility, hazard and risk zones.

- The basis upon which the zoning has been carried out including data sources, zoning methodology, the time period covered by the landslide inventory if one has been used to assess landslide frequency.

- A description of any limitations of the zoning including accuracy of zone boundaries.

- $\quad$ Other information to explain the use of the landslide zoning as required for the particular project.

This informs those who are using the landslide zoning and facilitates peer review. 


\section{RELIABILITY OF LANDSLIDE ZONING FOR LAND USE PLANNING}

\subsection{POTENTIAL SOURCES OF ERROR}

\subsubsection{Description}

There are a number of potential sources of error in the zoning process. These include:

- Limitations in the landslide inventory upon which the susceptibility and hazard zoning maps are based.

- Limitations in the stability of temporal series. For example the relationship between the triggering factor (e.g. rainfall) and the frequency of landslides may change if the area is deforested.

- Limitations in the level of detail available of topography, geology, geomorphology, rainfall and other input data.

- Model uncertainty, meaning the limitations of the methods used to relate the inventory, topography, geology, geomorphology and triggering events such as rainfall to predicting landslide susceptibility, hazard and risk.

- Limitations in the skill of the persons carrying out the zoning.

It must be recognised that landslide zoning is not a precise science and the results are only a prediction of performance of the slopes based on the available data. In general, intermediate or advanced level zoning will be less subject to error than preliminary level zoning with each done at a suitable zoning map scale.

\subsubsection{Landslide inventories}

Cascini et al. (2005) conclude that the greatest source of error is limitations in the inventory. They give examples showing gross mismatch of inventory maps for landsliding from the same area of natural slopes prepared by two groups. They point out that the greatest errors occur when inventories rely on air photo interpretation, particularly of small scale photography. These errors are in part due to the subjective nature of aerial photo interpretation but also to vegetation covering the areas to be mapped. Aerial photographic mapping should be supported by surface mapping of selected areas to calibrate the mapping.

Inventories of landsliding of cuts, fills and retaining walls on roads, railways and urban development will seldom be complete. To get a reasonable estimate of the number of slides the zoning will have to make a judgement about the proportion of the slides which have been recorded.

\subsubsection{Topographic maps}

Good topographic maps are most important input to zoning at intermediate and advanced levels. Topographic maps facilitate the modelling and mapping of landslide zoning boundaries with an appropriate accuracy. For large scale zoning, contours at 2 metre or at most 5 metre intervals will be required. Even then, zoning boundaries should be checked on the ground because the implications for land owners of errors in boundaries can be significant.

\subsubsection{Model uncertainty}

Model uncertainty is a fact of landslide zoning and none of the methods are particularly accurate. In general terms hazard and risk zoning based on statistical analyses of the input data using intermediate level inputs will give the best accuracy.

Sophisticated methods for assessing the inputs rely on carrying out calculations (for example of the factor of safety of a slope) which have a theoretical attraction and the appearance of being able to produce better accuracy. In reality the parameter uncertainty is large due to limitations in the knowledge of the input data (such as shear strength and pore pressures) and these make it very difficult to achieve any greater accuracy than other modelling methods.

\subsection{VALIDATION OF MAPPING}

\subsubsection{Peer review}

For most zoning studies for land use planning there should be a peer reviewer appointed to provide independent assessment of the susceptibility, hazard and risk zoning. The peer reviewer should have a high level of the skills and experience listed in Section 11.2. The peer reviewer should meet with those carrying out the study at the beginning of the study and, depending on the scale of the projects, perhaps after initial mapping and then as the zoning is being 


\section{GUIDELINE FOR LANDSLIDE SUSCEPTIBILITY, HAZARD AND RISK ZONING}

finalised. This process is a basic form of quality control and a form of validation if the peer reviewer has appropriate wide experience.

\subsubsection{Formal validation}

For more important advanced level mapping projects there can be a process of validation within the study. To do this the landslide inventory is randomly split in two groups: one for analysis and one for validation. The analysis is carried out in part of the study area (model) and tested in another part with different landslides. An alternative approach for advanced mapping projects is for an analysis to be carried out with landslides that have occurred in a certain period whilst validation is performed upon landslides that have occurred in a different period. Validation can also be carried out by this process after the mapping and land use planning scheme has been in place for some time. This is really only practical for high frequency landsliding because of the time frame required to gather performance data.

\subsection{POTENTIAL EFFECTS OF CLIMATE CHANGE}

There is a developing knowledge of climate change and the effects of this on rainfall and snowfall. It could be anticipated that for example a decreased frequency of high intensity rainfall might reduce the frequency of shallow landslides on steep hill slopes. However the science of prediction of the effects of climate change and the prediction of the frequency of landslides from rainfall is not sufficiently advanced at this time to warrant consideration of climate change when carrying out zoning studies.

Those involved in landslide zoning studies should keep informed of developments which might alter this conclusion.

\section{APPLICATION OF LANDSLIDE ZONING FOR LAND USE PLANNING}

\subsection{GENERAL PRINCIPLES}

These guidelines are for landslide susceptibility, hazard and risk zoning. Those who are considering the introduction of land use management controls for landsliding need to decide the type and level of zoning which they require based on the purpose of the zoning. This is detailed in Section 6. They may choose to stage the zoning and implementation of land use controls.

It should be recognised that it is not possible to delineate zoning boundaries accurately with regional and local zoning using small and medium scale zoning maps. This can only be done using local or site-specific zoning and large to detailed scale maps.

It is critical that the local governmental authority or other organization requiring the zoning, clearly and fully define the purpose and nature of any zoning study, understand the existing availability of potential input data, assess the implications for acquisition of new data and then define realistic goals for the zoning study taking into account, timeframes, budgets and resource limitations.

It should be noted that mapping will usually result in lines on a map delineating for example the landslide hazard zones based on contours and geomorphologic boundaries. However, for land use planning and zoning purposes the zone boundaries are often re-drawn to coincide with allotment boundaries for administrative reasons. This may lead to adoption of conservative boundaries and should be avoided where practical.

\subsection{TYPICAL DEVELOPMENT CONTROLS APPLIED TO LANDSLIDE ZONING}

Examples of the types of development controls which are applied to landslide zoning are:

- If zoning is by susceptibility the controls usually require geotechnical assessment of hazard and risk of the proposed development for zones determined as susceptible to landsliding whilst only minimal requirements (such as adherence to good hillside practice) in areas determined as very low susceptibility or not susceptible.

- If zoning is by hazard and the study has been done at an intermediate or advanced level it should be possible to delineate land use zones where: (a) Hazard is so low that no development controls are necessary; (b) Where some prescriptive controls such as limits to the heights of cuts and fills are necessary; (c) Where detailed geotechnical assessment of the hazard and risk is required before development can be approved and (d) Where the hazard is so high no development is possible.

- Where zoning is by life loss risk and the study has been done at an intermediate or advanced level, it should be possible to delineate land use zones where (a) Life loss risk is so low no development controls are necessary; (b) Where site specific assessment of the risk is required prior to approval of development and (c) Where the risk is so high that no development is possible. 


\section{GUIDELINE FOR LANDSLIDE SUSCEPTIBILITY, HAZARD AND RISK ZONING}

In practice those considering landslide zoning for land use management would be well advised to seek advice from a Geotechnical Professional who is familiar with landslide zoning and risk management to provide advice in planning the landslide zoning study and applying the outcomes to land use planning.

\subsection{NEED TO REVIEW AND UP-DATE LANDSLIDE ZONING}

It should be recognised that there should be periodic reviews of landslide zoning because:

- $\quad$ The susceptibility, hazard and risk may be altered by development and land-use changes subsequent to the study.

- The state of knowledge of landsliding in the area will be improved with more detailed investigations carried out as part of the development.

- $\quad$ The elements at risk may change with time so landslide risk zoning should be reviewed to allow for this.

- Methods of landslide zoning are evolving so in combination with the factors listed above, improved zoning will be possible.

It is recommended that reviews be carried out at intervals no greater than about 10 years. In some cases more frequent reviews will be necessary.

\section{HOW TO BRIEF AND SELECT A GEOTECHNICAL PROFESSIONAL TO UNDERTAKE A ZONING STUDY}

\subsection{PREPARING A BRIEF}

The following are some matters which should be considered in preparing a brief for a landslide zoning study.

- $\quad$ Define the purpose of the zoning and how it will be used.

- $\quad$ Define the area to be zoned.

- Define what type of zoning is required: landslide susceptibility, hazard or risk.

- Define the level of zoning required and whether it will be staged.

- Identify the various stake holders and their interests.

- $\quad$ Describe what, if any, public consultation process will be required.

- State relevant legal and regulatory controls.

- Set out the documentation required for the results of the zoning, including details of what maps are required, map scales, and electronic formats and the supporting report describing the zoning processes, methods used, validation and limitations.

- Set a program for the study.

- $\quad$ Set a budget consistent with the scope and expectations of the study.

- Describe the peer review process which will apply.

- List the available data and the format it is in.

- $\quad$ Detail the expected method for the study.

- $\quad$ Define the terminology to be used to describe susceptibility, hazard and risk.

In so far as possible, this is best done in consultation with prospective consultants so there is a clear understanding of what is required.

\subsection{SELECTING A CONSULTANT FOR THE ZONING}

Landslide susceptibility, hazard and risk zoning is a science that should be done by well qualified geotechnical professionals who are experienced in mapping and who understand slope processes, risk assessment and geotechnical slope engineering. This will usually mean that a team of professionals will be needed including an engineering geologist, geomorphologist (for zoning of natural slopes where geomorphology mapping is required) and a geotechnical engineer. It should be noted that only a few engineering geologists and geotechnical engineers are experienced in geomorphologic mapping. It is essential that geotechnical engineers who understand the soil and rock mechanics of slope processes pre and post-failure are involved in the landslide susceptibility, hazard and risk assessments.

Consultants proposing to carry out landslide zoning should demonstrate they have personnel who will work on the project with the relevant skills and experience. It is not sufficient that a geotechnical company has done such studies because it is the personnel directly involved that are important. 


\section{GUIDELINE FOR LANDSLIDE SUSCEPTIBILITY, HAZARD AND RISK ZONING}

One means of demonstrating competence is through registration upon the National Professional Engineering Register (NPER) under the specific area of practice for Landslide Risk Management (LRM).

\subsection{PROVIDE ALL RELEVANT DATA}

It is essential that the consultant is provided with all the available data regarding the incidence of landsliding in the study area. There should be a thorough search of records from files and works reporting repairs that have been carried out.

Where there is limited data on the incidence of landslides in the area those responsible will greatly benefit by establishing and maintaining a landslide inventory.

\section{ACKNOWLEDGEMENTS}

These guidelines have been prepared by The Australian Geomechanics Society with funding from the National Disaster Mitigation Program, the Sydney Coastal Councils Group, and The Australian Geomechanics Society.

The Australian Geomechanics Society established a Working Group within a Landslide Taskforce to develop the guidelines. The development of the guidelines was managed by a Steering Committee. Membership of the Working Group, Taskforce and Steering Committee is listed in Appendix B.

Concurrent with the development of the AGS guidelines, JTC-1, the Joint International Societies Technical Committee on Landslides and Engineered Slopes has been developing International Guidelines on Landslide Susceptibility, Hazard and Risk Zoning. Those guidelines have been prepared under the technical direction of a Scientific Committee. Membership of the JTC-1 Scientific Committee is attached in Appendix C.

Drafts of the AGS guideline have been subject to review by members of the AGS Landslide Taskforce, members of the geotechnical profession and local government.

Drafts of the International Guidelines have received extensive consideration and discussion and in a Workshop held in Barcelona from $18^{\text {th }}$ to $20^{\text {th }}$ September 2006. Later drafts of the guideline have been reviewed by attendees to the Barcelona Workshop and members of JTC-1. There has been an integrated approach between the groups developing the guidelines and they are similar except for details specific to AGS requirements.

\section{REFERENCES}

AGS (2000). Landslide risk management concepts and guidelines. Australian Geomechanics Society. Australian Geomechanics Vol 35, No 1, 49-92

AGS (2002). Landslide risk management concepts and guidelines. Australian Geomechanics Society. Australian Geomechanics Vol 37, No 2, 1-44

AGS (2007a). Guideline for Landslide Susceptibility, Hazard and Risk Zoning for Land Use Management. Australian Geomechanics Society, Australian Geomechanics, Vol 42, No1.

AGS (2007b). Commentary on Guideline for Landslide Susceptibility, Hazard and Risk Zoning for Land Use Management, Australian Geomechanics Society, Australian Geomechanics, Vol 42, No1.

AGS (2007c).. Practice Note Guidelines for Landslide Risk Management Australian Geomechanics Society. Australian Geomechanics, Vol 42, No1.

AGS (2007d). Commentary on Practice Note Guidelines for Landslide Risk Management. . Australian Geomechanics, Vol 42, No1,

AGS (2007e). Australian GeoGuides for Slope Management and Maintenance. Australian Geomechanics Society. Australian Geomechanics, Vol 42, No1,

Cascini, L.; Bonnard, Ch.; Corominas, J.; Jibson, R. and Montero-Olarte, J. (2005). Landslide hazard and risk zoning for urban planning and development. In Landslide Risk Management O. Hungr, R. Fell, R. Couture and E. Eberthardt (editors). Taylor and Francis, London. 199-235

Cruden, D.M., and Varnes, D.J. (1996), Landslide Types and Processes, in Landslides. Investigation and Mitigation, Editors AK Turner. and RL Schuster. Special Report 247, Transport Research Board, National Research Council, Washington D.C.

Fell, R., Ho, K.K.S., Lacasse, S. and Leroi, E. (2005). A framework for landslide risk assessment and management. In Landslide Risk Management, Editors O Hungr, R Fell, R Couture and E Eberhardt, Taylor and Francis, London,3-26

Hutchinson, J.N. (1988). Morphological and geotechnical parameters of landslides in relation to geology and hydrogeology. In Ch. Bonnard (Ed.): Landslides. Proceedings 5th International Conference on Landslides. Lausanne. Vol. 1: 3-35 
IAEG (1990). Suggested nomenclature for landslides. International Association of Engineering Geology Commission on Landslides,, Bulletin IAEG, No. 41,.13-16.

IUGS (1997). Quantitative risk assessment for slopes and landslides- The state of the art. In Landslide Risk Assessment D. Cruden and R. Fell (editors). Balkema, Rotterdam. pp. 3-12.

Leroi, E., Bonnard,C., Fell, R. and McInnes, R (2005) Risk assessment and management. In Landslide Risk Management, Editors O Hungr, R Fell, R Couture and E Eberhardt, Taylor and Francis, London, 159-198

Varnes, D.J. (1978). Slope Movement Types and Processes. In Special Report 176: Landslides: Analysis and Control, editors R.L. Schuster and R.J. Krizek, TRB, National Research Council, Washington, D.C.,.11-33. 


\section{GUIDELINE FOR LANDSLIDE SUSCEPTIBILITY, HAZARD AND RISK ZONING}

\section{APPENDIX A - DEFINITION OF TERMS}

Acceptable Risk - A risk which, for the purposes of life or work, society is prepared to accept as it is with no regard to its management. Society does not generally consider expenditure in further reducing such risks justifiable.

Annual Exceedance Probability (AEP) - The estimated probability that an event of specified magnitude will be exceeded in any year.

Consequence - The outcomes or potential outcomes arising from the occurrence of a landslide expressed qualitatively or quantitatively, in terms of loss, disadvantage or gain, damage, injury or loss of life.

Danger - The natural phenomenon that could lead to damage, described in terms of its geometry, mechanical and other characteristics. The danger can be an existing one (such as a creeping slope) or a potential one (such as a rock fall). The characterisation of a danger does not include any forecasting.

Elements at Risk - The population, buildings and engineering works, economic activities, public services utilities, infrastructure and environmental features in the area potentially affected by landslides.

Frequency - A measure of likelihood expressed as the number of occurrences of an event in a given time. See also Likelihood and Probability.

Hazard - A condition with the potential for causing an undesirable consequence.. The description of landslide hazard should include the location, volume (or area), classification and velocity of the potential landslides and any resultant detached material, and the probability of their occurrence within a given period of time.

Individual Risk to Life - The risk of fatality or injury to any identifiable (named) individual who lives within the zone impacted by the landslide or who follows a particular pattern of life that might subject him or her to the consequences of the landslide.

Landslide inventory -An inventory of the location, classification, volume, activity and date of occurrence of landsliding

Landslide activity -The stage of development of a landslide; pre-failure when the slope is strained throughout but is essentially intact; failure characterized by the formation of a continuous surface of rupture; post-failure which includes movement from just after failure to when it essentially stops and reactivation when the slope slides along one or several pre-existing surfaces of rupture. Reactivation may be occasional (e.g. seasonal) or continuous (in which case the slide is "active")

Landslide Intensity - A set of spatially distributed parameters related to the destructive power of a landslide. The parameters may be described quantitatively or qualitatively and may include maximum movement velocity, total displacement, differential displacement, depth of the moving mass, peak discharge per unit width, kinetic energy per unit area.

Landslide Susceptibility - A quantitative or qualitative assessment of the classification, volume (or area) and spatial distribution of landslides which exist or potentially may occur in an area. Susceptibility may also include a description of the velocity and intensity of the existing or potential landsliding.

Likelihood - Used as a qualitative description of probability or frequency.

Probability - A measure of the degree of certainty. This measure has a value between zero (impossibility) and 1.0 (certainty). It is an estimate of the likelihood of the magnitude of the uncertain quantity or the likelihood of the occurrence of the uncertain future event.

There are two main interpretations:

(i) Statistical - frequency or fraction - The outcome of a repetitive experiment of some kind like flipping coins. It includes also the idea of population variability. Such a number is called an "objective" or relative frequentist probability because it exists in the real world and is in principle measurable by doing the experiment.

(ii) Subjective probability (degree of belief) - Quantified measure of belief, judgement, or confidence in the likelihood of a outcome, obtained by considering all available information honestly, fairly and with a minimum of bias. Subjective probability is affected by the state of understanding of a process, judgement regarding an evaluation or the quality and quantity of information. It may change over time as the state of knowledge changes.

Qualitative Risk Analysis - An analysis which uses word form, descriptive or numeric rating scales to describe the magnitude of potential consequences and the likelihood that those consequences will occur.

Quantitative Risk Analysis - an analysis based on numerical values of the probability, vulnerability and consequences, and resulting in a numerical value of the risk. 


\section{GUIDELINE FOR LANDSLIDE SUSCEPTIBILITY, HAZARD AND RISK ZONING}

Risk - A measure of the probability and severity of an adverse affect to health, property or the environment. Risk is often estimated by the product of probability $\mathrm{x}$ consequences. However, a more general interpretation of risk involves a comparison of the probability and consequences in a non-product form.

Risk Analysis - The use of available information to estimate the risk to individuals, population, property or the environment from hazards. Risk analyses generally contain the following steps: scope definition, hazard identification and risk estimation.

Risk Assessment - The process of risk analysis and risk evaluation.

Risk Control or Risk Treatment - The process of decision making for managing risk and the implementation or enforcement of risk mitigation measures and the re-evaluation of its effectiveness from time to time, using the results of risk assessment as one input.

Risk Estimation - The process used to produce a measure of the level of health, property or environmental risks being analysed. Risk estimation contains the following steps: frequency analysis, consequence analysis and their integration.

Risk Evaluation - The stage at which values and judgements enter the decision process, explicitly or implicitly, by including consideration of the importance of the estimated risks and the associated social, environmental and economic consequences, in order to identify a range of alternatives for managing the risks.

Risk Management - The complete process of risk assessment and risk control (or risk treatment).

Societal Risk - The risk of multiple fatalities or injuries in society as a whole: one where society would have to carry the burden of a landslide causing a number of deaths, injuries, financial, environmental and other losses.

\section{Susceptibility - see Landslide Susceptibility}

Temporal-Spatial Probability - The probability that the element at risk is in the affected area at the time of the landslide.

Tolerable Risk - A risk within a range that society can live with so as to secure certain net benefits. It is a range of risk regarded as non-negligible and needing to be kept under review and reduced further if possible.

Vulnerability - The degree of loss to a given element or set of elements within the area affected by the landslide hazard. It is expressed on a scale of 0 (no loss) to 1 (total loss). For property, the loss will be the value of the damage relative to the value of the property; for persons, it will be the probability that a particular life (the element at risk) will be lost, given the person(s) is affected by the landslide.

Zoning: The division of land into homogeneous areas or domains and their ranking according to degrees of actual or potential landslide susceptibility, hazard or risk. 


\section{APPENDIX B - TASKFORCE MEMBERS \\ AUSTRALIAN GEOMECHANICS SOCIETY}

\section{STEERING COMMITTEE}

Andrew Leventhal, GHD Geotechnics, Sydney, Chair.

Robin Fell, School of Civil and Environmental Engineering, UNSW, Sydney, Convenor,Guidelines on Landslide Susceptibility, Hazard and Risk Working Group.

Tony Phillips, Consultant, Sydney, Convenor Slope Management and Maintenance Working Group.

Bruce Walker, Jeffery and Katauskas, Sydney, Convenor Practice Note Working Group.

Geoff Withycombe, Sydney Coastal Councils Group, Sydney

WORKING GROUP - Guidelines on Landslide Susceptibility, Hazard and Risk

Robin Fell, School of Civil and Environmental Engineering, UNSW, Sydney, Convenor

Graham Whitt, Shire of Yarra Ranges, Lillydale

Tony Miner, A.G. Miner Geotechnical, Geelong

Phil Flentje, University of Wollongong.

\section{TASKFORCE}

Laurie de Ambrosis, GHD Geotechnics, Sydney

Mark Eggers, Pells Sullivan Meynink, Sydney

Max Ervin, Golder Associates, Melbourne

Angus Gordon, retired, Sydney

Greg Kotze, GHD, Sydney

Arthur Love, Coffey Geotechnics, Newcastle

Alex Litwinowicz, GHD Geotechnics, Brisbane

Tony Miner, A.G. Miner Geotechnical, Geelong

Fiona MacGregor, Douglas Partners, Sydney

Garry Mostyn, Pells Sullivan Meynink, Sydney

Grant Murray, Sinclair Knight Merz, Auckland

Garth Powell, Coffey Geotechnics, Brisbane

Ralph Rallings, Pitt and Sherry, Hobart

Ian Stewart, NSW Roads and Traffic Authority, Sydney

Peter Tobin, Wollongong City Council, Wollongong

Graham Whitt, Shire of Yarra Ranges, Lillydale

\section{APPENDIX C - JTC-1 MEMBERS \\ JTC-1 JOINT TECHNICAL COMMITTEE ON LANDSLIDES AND ENGINEERED SLOPES}

SCIENTIFIC COMMITTEE

Robin Fell, University of New South Wales, Australia

Jordi Corominas, Technical University of Catalonia-UPC, Barcelona, Spain

Christophe Bonnard, École Polytechnique Féderale, Lausanne, Switzerland

Leonardo Cascini, University of Salerno, Italy

Eric Leroi, Urbater, France

Bill Savage, United States Geological Survey, Golden, Colorado, USA 